\title{
CFO Compensation: Evidence from Australia
}

\begin{abstract}
We investigate the extent to which the incentive alignment theory and the managerial power theory explain the variability of CFO compensation in Australia. We find a positive relationship between the level of CFO compensation and measures of job complexity and firm stock market performance. However, we do not find the pay-for-performance link when performance is measured at the CFO-specific level. CFOs actually receive higher non-cash compensation when reporting quality is lower, suggesting a sharp contrast to predictions of the incentive alignment approach. Conversely, we find that CFOs who have more managerial power (the CFO is on the board of directors, or holds a higher level of stock ownership, or stays longer in their position) receive significantly higher compensation. For example, a CFO who has board membership receives on average $\$ 323,590$ more than the total compensation of a CFO who is not a board insider. Overall both theories are important in determining Australian CFO compensation but the managerial power hypothesis explains a larger fraction of variation in CFO pay than the incentive alignment view.
\end{abstract}

Keywords: CFO Compensation, Job Complexity, Performance, Managerial Power.

JEL classification: G34, J33, M41 


\section{Introduction}

Chief Financial Officers (CFOs) are financial stewards of companies and their main roles are to prepare financial statements, strategic planning and to assist in the development of company policies. ${ }^{1}$ Legislative and media attention has recently been directed towards CFOs and the role they play in creating and disseminating financial information. In the wake of financial frauds and subsequent collapses of several high-profile corporations, legislators and the media are centering their blame not only on the Chief Executive Officers (CEOs) who have final oversight authority for the company, but also on the CFOs. As a consequence, the US Congress enacted the Sarbanes-Oxley Act (SOX) 2002, and of particular relevance is Section 302 of this Act which requires both CEOs and CFOs to certify the material accuracy and completeness of the financial information and related disclosures by the company. The legislative elevation of CFOs to the same level of financial oversight responsibility as CEOs has emphasized the important role of CFOs beyond that of other company executives. ${ }^{2}$

Australia has had a number of high-profile cases, such as One.Tel, HIH Insurance and Centro, which focused attention on corporate governance and reporting quality. The Australian Government has also been actively engaged in attempting to strengthen corporate disclosures and the financial reporting framework. Section 295A of the Corporations Act in Australia requires both CEOs and CFOs of listed entities to sign off on their company annual accounts and to declare that the company's financial reports present "a true and fair view in accordance with relevant accounting standards". As an outcome of legislative elevation of CFOs, the US Securities and Exchange Commission (SEC) has required disclosure about CFO compensation since December 2002. ${ }^{3}$ In Australia, the Corporate Law and Economic Reform Program (Audit Reform and Corporate Disclosure) Act 2004 (also known as CLERP 9) became law in 1 July 2004. CLERP 9, for example, requires expanded disclosure of executive remuneration by introducing a remuneration report within the directors' report of company financial reports. With the increasing

\footnotetext{
${ }^{1}$ Recent research indicate that CFOs not only perform their traditional role of preparing statutory accounts, but have also moved into a "number two" position in firm hierarchy when developing strategic plans (Zorn 2004, Copeland et al. 2005, Heibl et al. 2013).

${ }^{2}$ There is evidence in the literature that CFOs possess superior information due to their roles in the firm's financial policy and financial reporting process (Geiger \& North 2006, Jiang et al. 2010). Wang et al. (2012) find that CFO trades are more informative about future stock returns than CEO trades. Specifically, they document that CFOs earn significantly higher abnormal returns following their purchases of company shares than CEOs.

${ }^{3}$ Some recent US studies have provided empirical evidence to support SEC's new disclosure requirement on CFO compensation by showing that the CFO's influence on company financial performance can be stronger than that of the CEO. For example, in a study of CEOs and CFOs influence on earnings management, Jiang et al. (2010) find that earnings management is significantly larger with CFO equity incentives than CEO equity incentives. Similarly, Chava \& Purnanandam (2010) note that CFOs equity incentives have relatively stronger power in explaining company debt structure and accruals management than that of CEOs.
} 
awareness of the significance of the CFO function to an organization, it is therefore important to address the question of compensation paid to a CFO.

There are two competing schools of thought in the literature on rewarding company executives. One view (the managerial power or rent extraction approach) is that powerful executives influence the board of directors into paying them a high compensation with little or no obligations attached (e.g. Core et al. 1999, Bebchuk et al. 2002). The other view (traditional or incentive alignment hypothesis) argues that executives are rewarded for skill, effort and performance (e.g. Jensen \& Meckling 1976, Jensen \& Murphy 1990). There are a number of empirical studies that test the explanatory power of each theory in relation to CEO compensation (e.g. Gristein \& Hribar 2004, Chalmers et al. 2006, Coakley \& Iliopoulou 2006, Bugeja et al. 2012). However, little academic research has been undertaken to examine the relative effect of each hypothesis on CFO compensation. Although a number of studies examine the determinants of CFO compensation with reference to either of the above-mentioned views (e.g. Indjejikian \& Matejka 2009, Balsam et al. 2012, Bedard et al. 2014), no work has been done on assessing the relative power of each theory on CFO remuneration.

The relationship between CEO remuneration, governance characteristics and performance is generally well understood and documented. Following the recommendation of CLERP 9 that executive remuneration should be continuously disclosed and monitored by the relevant industries and professional bodies, there is now a heightened awareness of remuneration paid to CFOs and a gap as to the underlying determinants of this pay. In line with the two competing theories, our work addresses two research questions. Firstly, to what extent is CFO compensation paid to align CFO incentives with value maximization? Secondly, to what extent do powerful CFOs extract rent through excessive pay? Our study contributes to the literature by testing the relatively explanatory power of the incentive alignment and managerial power theories on $\mathrm{CFO}$ compensation. By doing this, our study responds to the recommendation of CLERP 9 requiring close scrutiny of executive remuneration. Our CFO remuneration and corporate governance data is obtained from Capital IQ and annual reports, and is collected for the period 2006-2010.

By examining the determinants of Australian CFO compensation, we investigate if the US findings also apply to Australia. It is acknowledged that both countries have some similar features

\footnotetext{
${ }^{4}$ Capital IQ database has data on CFO remuneration and $\mathrm{CFO}$ characteristics, however, there are a number of missing observations, particularly in the earlier years. For example, the name of companies and CFOs are in the database but without remuneration, share ownership and appointment date. Consequently, we have manually extracted missing data from company financial reports.
} 
including shareholder-oriented corporate culture and a regulatory framework which requires CFOs to certify company financial reports. In addition, following the Global Financial Crisis (GFC), both countries enacted clawback provisions requiring executives to pay back remuneration in the event of a material misstatement subsequently found in the company's financial statements. There are, however, some distinctions between Australia and the US in the structure of corporate governance and in the way CFOs are being remunerated. One observable difference is in the composition of the board of directors. The board structure of Australian firms differs markedly from their US counterparts with Australian boards more closely conforming to "best practice" (Kiel \& Nicholson 2003). Specifically, Australian boards are, on average, smaller and have a lower proportion of independent directors (Bugeja et al. 2012). Furthermore, the fraction of Australian CFOs who sit on the board of directors is much higher than that in the US. There are roughly $43 \%$ of Australian-listed companies with CFOs as board insiders, but this proportion is much lower in the US market which ranges from $8.6 \%$ (Bedard et al. 2014) to $15.1 \%$ (Balsam et al. 2012). This difference coupled with the earlier cited difference of a lower proportion of non-executive directors leads to CFOs in Australia taking on a more strategic role. Another difference is in the way CFOs are being compensated. Similar to CEO remuneration (e.g. Ferreira et al. 2013), our data shows that the cash component (salary and bonus) paid to Australian CFOs account for a higher proportion, while the remuneration of the US counterparts is more heavily weighted towards the non-cash component such as shares and options (Balsam et al. 2012, Bedard et al. 2014). This is due, in part, to the Australian tax framework where shares, options and other rights are assessed and taxed on receipt. One of the distinguished differences between the two countries is that Australia in July 2011 legislated a "two-strikes" rule which provides shareholders more empowerment over executive remuneration. Under the new legislation, ${ }^{5}$ if the remuneration report of a firm receives $25 \%$ or more dissent votes for two consecutive years ("two strikes"), the board of directors except the CEO may face re-election.

For our analysis, we sample 563 firm-year observations over the period from 2006 to 2010 and investigate which theory (incentive alignment or managerial power) best explains the variation in Australian CFO compensation. In our study, we find that these two theories are not mutually exclusive and both have explanatory power in explaining CFO compensation. Consistent with the incentive alignment view, we find that measures of job complexity and firm stock market performance are positively related to the level of CFO compensation, indicating that CFOs are

\footnotetext{
${ }^{5}$ This Australian new legislation, the "two-strikes" rule, is in the Corporations Amendment (Improving Accountability on Director and Executive Remuneration) Act 2011.
} 
paid for their skill, effort and firm overall performance. However, a measure of CFO-specific performance, that is, the absolute value of discretionary accruals, does not explain the crosssectional variation in the CFO compensation. In fact, the discretionary accruals variable is positively associated to the non-cash component of CFO compensation which is not consistent with the predictions of the traditional view. Such a finding is indicative of CFOs actually receiving higher non-cash remuneration for delivering lower reporting quality. On the other hand, we find no inconsistent results for the rent extraction theory. All measures of managerial power significantly explain the variation in the level of CFO compensation. CFOs that have more power, as defined by board membership, level of company stock ownership, tenure and board size, are likely to extract higher rent through compensation. Our findings generally offer more support to the managerial power approach rather than the incentive alignment view with respect to CFO compensation.

The remainder of this paper is as follows. Section 2 reviews the literature on CFO compensation, articulates the research questions and provides a brief background on the two underlying theories. Section 3 describes the regression model and the data sampling process. In Section 4, empirical results are presented and discussed. Finally, concluding comments are provided in Section 5 .

\section{Literature review}

The traditional view or the incentive alignment perspective argues that the board should offer its executives compensation packages that maximise shareholder value (Jensen \& Meckling 1976, Haugen \& Senbet 1981). The incentive alignment theory assumes that optimal compensation packages can mitigate agency problems (Jensen \& Meckling 1976, Jensen \& Murphy 1990). It also asserts that executive compensation is a function of the supply and demand for manager's skills, effort and performance. The opposing view is the managerial power approach or rent extraction theory. As defined by Finkelstein (1992), managerial power is the ability of managers to influence or exert their will on the remuneration decisions made by the board of directors. Under this approach, managerial power creates the ability for management to obtain a compensation package that is sub-optimal and consequently reduces shareholder wealth (Core et al. 1999, Bebchuk et al. 2002).

There is some evidence in the literature that the traditional view is subject to a moral hazard 
problem. For example, Mirrlees (1976) and Grossman \& Hart (1983) show that managers do not necessarily maximise shareholder wealth since their actions are unobservable to shareholders and they have incentives to maximise their personal benefits. In the presence of this moral hazard the board needs to design a compensation package that aligns managerial incentives with observable measures such as company stock returns and profitability measures that maximise firm and shareholder value. There are numerous studies, both within Australia (Chalmers et al. 2006, Schultz et al. 2013) and international (McConnell \& Servaes 1990, Jensen \& Murphy 1990, Ozkan 2011), that support the CEO pay-for-performance link. In a study of Australian CEO compensation following mergers and acquisitions, Bugeja et al. (2012) not only find a positive association between CEO compensation and firm performance, but also document a positive correlation between CEO compensation and a number of measures of CEO effort and skill in completing the deal thereby providing support to the incentive alignment theory. Given the growing accountability and importance attached to the role of CFOs, particularly over the last decade, there is now a growing interest in replicating the work done on CEO compensation for CFOs to better understand the determinants of CFO compensation and performance.

Consistent with the traditional view, there are numerous studies in the literature providing evidence that CFOs are rewarded for their skill, effort and performance. Zamora (2009) finds that CFOs who are classified as superior forecasters receive higher bonus and equity pay. Gore et al. (2011) examine the effect of corporate governance on CFO incentive compensation and find that firms with more financial expert use fewer incentives in compensating their CFOs. Loyeung \& Matolcsy (2015) document that Australian CFOs have received higher bonus for their accounting talent, measured as the inverse ratio of the absolute value of accounting errors scaled by total assets, following the mandatory adoption of International Financial Reporting Standards (IFRS). ${ }^{6}$ Likewise, Balsam et al. (2015) document an increase in executive compensation following the mandatory adoption of IFRS. This increase in executive compensation is found to be related to increased responsibility and in addition is greater for CFOs than CEOs. These findings provide support to the incentive alignment approach, namely, that firms offer higher compensation to attract talented CFOs.

In related studies on CFO compensation and financial reporting quality in the form of internal control and accounting restatements, Wang (2010) finds that CFOs of companies with strong

\footnotetext{
${ }^{6}$ Loyeung \& Matolcsy (2015) find a positive relationship between CFOs' talent and their compensation levels (base salary, cash salary and total compensation) in the IFRS transition year. In addition, talented CFOs are awarded higher bonuses in the subsequent (adoption) year when errors in implementing IFRS are reported.
} 
internal controls receive higher compensation. Hoitash et al. (2012) document that changes in $\mathrm{CFO}$ compensation are significantly related to internal control material weakness (ICMW) disclosures. They are unable to uncover any significant association between ICMW disclosures and changes in CEO compensation measure even though CEOs are primarily responsible for certifying internal control reports. The result from Balsam et al. (2014) study is consistent with the incentive alignment view that equity-based compensation increases management's incentives to maintain higher internal control quality, and CFO incentives are more important than CEO incentives. In addition, Collins et al. (2008) and Bedard et al. (2014) document the negative relationship between accounting restatements and CFO bonus and total cash compensation.

A number of studies have also directly examined the pay-for-performance link for CFOs. Indjejikian \& Matejka (2009) find that annual bonuses are the most common incentive component of CFO compensation plans with approximately $50 \%$ of CFO bonuses being paid on accounting financial performance. Bedard et al. (2014) show a significantly positive association between company stock market returns and CFO compensation. Balsam et al. (2012) observe that CFOs are not only rewarded based on the traditional firm performance (accounting and stock returns measures), but are also compensated based on other factors using a variety of job complexity measures and CFO-specific performance. Specifically, they conclude that both job complexity and overall firm performance positively affect CFO salary and bonus, while CFO individual performance affects the CFO bonus only.

Although executive compensation is normally set against a list of market factors, these factors are not strong enough to compel optimal contracting outcomes, and executives can still use their power to influence their compensation arrangements and to extract rents (Bebchuk \& Fried 2003). As argued by Bebchuk et al. (2002), a zero level of rent extraction is unlikely due to monitoring and incentive aligning devices being very costly. Bebchuk \& Fried (2004) contend that the managerial power hypothesis provides a stronger explanation of executive remuneration arrangements than the traditional view of optimal contracting. Morse et al. (2011) argue that the structure of the incentive contract can be manipulated by powerful CEOs even though the measures of performance may be appropriate. In their model, the incentive pay contract may be engineered by powerful CEOs as the CEOs initiate intentional strategies to shift weights on performance measure toward the better performing measures. Similarly, Adams et al. (2005) empirically show that firms having powerful CEOs experience more variability in performance. Under the managerial power approach, executive compensation will be higher for managers in 
corporations where they have relatively more power. Empirical research on CEO compensation in the US (Core et al. 1999, Bebchuk et al. 2002, Gristein \& Hribar 2004), UK (Coakley \& Iliopoulou 2006) and Australia (Chalmers et al. 2006) give strong support for the managerial power hypothesis that there is a direct relationship between CEO power and their higher compensation. Previously mentioned with the stature and importance of the CFO role growing, it is timely to add to the literature with our understanding of the relationship between CFO power and compensation.

Consistent with the managerial power approach, the literature has evidenced that powerful CFOs can potentially extract rent through excessive pay. ${ }^{7}$ Balsam et al. (2012) and Bedard et al. (2014) show evidence that CFOs who have a seat on the board of directors can have significant influences on their compensation. They both find that CFOs who are board insiders earn higher cash compensation and total compensation compared with CFOs that are not board members. Bedard et al. (2014) argue that the significance of a CFO sitting on the board is analogous to that of a CEO chairing the board since those CFOs will also vote on many important issues including ratifying director pay, as well as creating interdependency. This line of thought has been widely disseminated in the CEO compensation literature where a proxy for CEO power is when the CEO is the chairman of the board (e.g. Bebchuk et al. 2002, Gristein \& Hribar 2004, Adams et al. 2005).

From the above discussion, there are clearly a number of studies in the US literature showing evidence that CFO compensation can be explained by the incentive alignment theory or the managerial power theory. Loyeung \& Matolcsy (2015) provide Australian evidence supporting the traditional view that CFOs are rewarded for their accounting talent when adopting the IFRS. However, unlike the CEO literature (e.g. Gristein \& Hribar 2004, Chalmers et al. 2006, Bugeja et al. 2012), none of the studies provides a direct test on the determinants of CFO compensation with reference to the two theories. In this study, we aim at filling this gap by investigating the extent to which CFO effort, skill, performance and power can determine their level of compensation. Although we recognize that these two theories are not mutually exclusive, our objective is to ascertain the extent to which each of these theories can explain the variation in CFO compensation. Specifically, two research questions are addressed in this paper. Firstly, to what extent is CFO compensation linked to their effort and performance? Secondly, are powerful CFOs more entrenched as measured by compensation? According to the traditional view,

\footnotetext{
${ }^{7}$ There is also evidence of the impact of CFO power in other areas. For example, Ge et al. (2011) show that CFO style is more reflected in accounting choices when the level of CFOs' discretion is high.
} 
CFO remuneration is positively related to measures of their effort and performance. Within the managerial power framework there should be a positive correlation between the level of CFO compensation and the level of their managerial power and CFO skill and performance should play a secondary role in explaining CFO compensation.

\section{Methodology and data collection}

\subsection{Research method}

The following model is estimated to capture the degree to which CFO compensation is consistent with either the traditional view or managerial power theory:

$$
\begin{aligned}
\text { CFOCompensation }=\alpha & +\beta_{i}(\text { JobComplexity })_{i}+\gamma_{j}(\text { Performance })_{j}+\delta_{k}(\text { CFOPower })_{k} \\
& +\theta_{n}(\text { ControlVariables })_{n}+[\text { YearDummies }]+[\text { IndustryDummies }]+\epsilon
\end{aligned}
$$

The dependent variable in equation (1) is the compensation paid to CFOs during the year. Consistent with prior research, we examine five types of CFO compensation: bonus only, salary only, total cash compensation (the sum of salary, bonus and other cash compensation), total non-cash compensation (the sum of restricted stock rewards and stock option awards granted to CFOs), and total compensation (the sum of total cash and non-cash compensation). Given that a number of firms do not pay bonuses or offer an equity component, there are two components of CFO compensation that have zero values, that is, bonus and total non-cash compensation. We therefore separate CFO compensation into two sub samples for the regression analysis. The first sub group is for compensation figures using dollar value (full sample) and the second sub group is for compensation figures measured in logarithmic scale (sample without zero-value compensation). Ordinary Least Squares (OLS) regression analysis is run for the both sub samples, and a tobit regression is additionally run for the sub sample with zero-value compensation.

There are three main sets of independent variables in the regression (1) as well as a number of control variables for company financial characteristics that are associated with executive compensation. The first set of variables proxy for the level of job complexity of CFOs. The second set of variables measure performance at both firm and CFO-specific level. The third set of variables capture CFO managerial power.

\section{Proxies for job complexity}

In line with the incentive alignment view, CFOs are compensated more for their enhanced effort 
and skill in doing their jobs. It is reasonable to assume that larger firms with more complex operations will demand higher quality managers and be rewarded with higher compensation. Smith \& Watts (1992), for example, find that larger firms pay their executives more than smaller firms due to greater complexity and responsibility. We use Firm Size, measured by the natural logarithm of company total assets in the previous year, as our first proxy for CFO job complexity. Another proxy for CFO job complexity is the Bus. Segments variable which is measured as the $\log$ of the number of business segments in which the firm operates. Rose \& Shepard (1997) find that firms pay CEOs a diversification premium as a result of the added responsibility that is associated with managing additional business segments. Balsam et al. (2012) also document a positive relationship between diversity and the level of CFO compensation. As the number of business segments increases, so does the number of mangers that the CFO has to communicate with and entities whose results they have to consolidate. Under the incentive alignment perspective, it is hypothesized that both variables measuring CFO job complexity are positively associated with CFO compensation.

\section{Measures of performance}

We also include measures of performance at both the firm and CFO-specific level as direct measures of effort are unobservable. Previous research (e.g. Balsam et al. 2012, Bedard et al. 2014) has consistently shown that CFO pay is a function of firm performance. We control for firm performance using both accounting and market performance measures. The market measure chosen is the company's annual common stock return (Stock Returns) and the selected accounting measure is return on assets $(R O A)$.

As CFOs are responsible for reporting company financial results, we include discretionary (abnormal) accruals ${ }^{8}$ as one measure of CFO performance. Numerous studies in the area of financial reporting quality (Francis et al. 2008, Bedard et al. 2014) often use discretionary accruals as an inverse measure of accruals quality. Bedard et al. (2014), in a recent study on CFOs, argue that companies that have lower accruals quality (higher abnormal accruals) imply lower financial reporting quality. A number of studies also demonstrate that CFOs play an active role in controlling abnormal accruals. Geiger \& North (2006) document that a firm's discretionary accruals are reduced during the appointment of a new CFO. Dejong \& Ling (2013) show that

\footnotetext{
${ }^{8}$ There is often a differentiation between non-discretionary (normal) and discretionary (abnormal) components of accounting accruals in the literature. While nondiscretionary accruals are the expected level of accruals for a company based on characteristics, such as, type of operating industry, company size and revenue growth, discretionary accruals are the unexpected component and are subject to executive judgment when reporting net income (Jones 1991, DeFond \& Park 2001).
} 
CFOs tend to have a larger influence on abnormal accruals than CEOs after controlling for firm policy decisions. They further find that CFOs tend to push accruals to zero, suggesting more "solid" earnings reported by CFOs than CEOs. Our proxy for accruals-based earnings quality is the absolute value of forward-looking discretionary accruals (Discret. Accruals) and is calculated as the absolute value of the difference between total accruals ${ }^{9}$ and estimated non-discretionary accruals using the modified Jones model developed by Dechow et al. (2003).

The incentive alignment approach predicts that firms with higher overall performance will provide better rewards to their CFOs. Furthermore, CFOs will receive higher remuneration if they deliver better financial reporting quality proxied as better accruals quality or lower accruals management. In the other words, it is hypothesized that CFO compensation will be positively related to Stock Returns and ROA variables, but is negatively associated with the magnitude of discretionary accruals under the traditional perspective.

\section{Measures of CFO power}

Following the literature on CEO power (e.g. Denis et al. 1997, Bebchuk \& Fried 2003, Gristein \& Hribar 2004, Adams et al. 2005) and CFO power (Balsam et al. 2012, Bedard et al. 2014), we use a number of variables to measure CFO managerial power. ${ }^{10}$ The first measure of CFO power is when the $\mathrm{CFO}$ is a member of the company board of directors (CFO Board). Our second measure is the percentage of company shares owned by the CFO (CFO Ownership). The third measure is the number of years since the CFO was appointed (CFO Tenure). CFOs that have a longer tenure with the firm, or have greater equity ownership, or have a seat on the board of directors are expected to exert greater influence over the board. Consequently, they are likely to extract more rent through remuneration.

In measuring CFO managerial power it is necessary to control for differing structures of the company board of directors. We use the number of directors on the board (Board Size) and the percentage of executive directors on the board (Insider Ratio) as measures of board governance characteristics. As evidenced in Rosenstein \& Wyatt (1990) and Yermack (1996), smaller boards and boards with higher proportions of outside directors are more effective and they may act to constrain executive compensation. It is, therefore, reasonable to state that the larger the number of board members and the higher proportion of insiders will result in greater CFO managerial

\footnotetext{
${ }^{9}$ Total accruals is measured as the difference between firm earnings before extraordinary items and cash flows from operations, scaled by the previous year's total assets.

${ }^{10}$ We acknowledge that measures of $\mathrm{CEO} / \mathrm{CFO}$ managerial power which are developed through choice could be potentially endogenous with other company characteristics.
} 
power. Under the managerial power approach, we hypothesize a positive relationship between all CFO power variables and the level of CFO compensation.

\section{Control variables}

Consistent with prior work on executive compensation, we include firm leverage, growth opportunity and firm risk as financial control variables. Firm leverage is calculated as total debt divided by the market value of equity. The firm growth opportunity is captured by the marketto-book equity ratio $\left(M / B\right.$ ratio), and is winsorized at the $1^{\text {st }}$ and $99^{\text {th }}$ percentiles in order to control for outliers in the data. Balsam et al. (2012) and Bedard et al. (2014) find that CFO compensation is higher for companies with greater investment/growth opportunities. To control for firm risk, we use the standard deviation of return on assets (Std $\operatorname{dev}(R O A))$ and the standard deviation of sales scaled by total assets (Std dev (Sales/TA)), both measured over the preceding 5 years. Bedard et al. (2014) find a positive association between firm risk and CFO compensation.

We also control for industry and time fixed effects due to the differences in CFO compensation across industries ${ }^{11}$ and over time. For example, Murphy (2013) find that executives in electric utilities earn significantly lower levels of compensation than their counterparts in other industries such as financial services. Agarwal (1981) also argues that managers may demand higher compensation as managerial talent is more scarce in some industries and during differing market cycles.

\subsection{Sample construction}

The sample is constructed from the Top 500 by market capitalization firms listed on the Australian Securities Exchange (ASX). The study period is for the years 2006 to 2010. Data on CFO compensation, CFO characteristics and corporate governance for each company are extracted from the S\&P Capital IQ database. Information is obtained from a firm's annual report when information in the S\&P Capital IQ database is not available. Company accounting and financial data are obtained from Aspect FinAnalysis database and we exclude from the sample all companies with a change in CFO in any year. Our final sample consists of 563 firm-year observations. Table 1 provides a summary of definitions of the variables used in the study together with the data sources.

\footnotetext{
${ }^{11}$ Firms are sorted according to their 2-digit Global Industry Classification System (GICS) codes.
} 
[Insert Table 1]

\subsection{Descriptive statistics}

Table 2 presents descriptive data with CFO compensation in Panel A, firm financial data in Panel B, board governance structures and CFO information in Panel C. As can be seen from Panel A of Table 2, Australian CFOs receive a mean annual total compensation of $\$ 1.16$ million for the years 2006-2010. The amount of compensation paid to a CFO is approximately $60 \%$ of what a CEO earns. Chalmers et al. (2006), in a study of Australian Top 200 firms over the period 1999-2002, find that the average total compensation paid to a CEO is $\$ 1.89$ million. CEOs earning double their finance chief counterparts is also reported in the Capital 2012 salaries survey published in the Australian Financial Review newspaper. ${ }^{12}$ In this survey, it is revealed that the 10 highest-paid CEOs received around $\$ 8.8$ million in the financial year 2011-2012 compared with $\$ 4.39$ million for the 10 highest-paid CFOs. Although CFOs are substantially paid less than CEOs as measured by total compensation, they are both awarded similar bonuses. Our data shows that the average bonus paid to CFOs is $\$ 281$ thousand while this amount for CEOs is $\$ 299$ thousand (Chalmers et al. 2006). Australian CFOs receive approximately $78 \%$ of their total compensation in cash and the remaining $22 \%$ in non-cash compensation. This is similar to the compensation structure paid to Australian CEOs whose remuneration is weighted heavily towards the cash component (Chalmers et al. 2006, Bugeja et al. 2012).

[Insert Table 2]

Panel B of Table 2 describes the financial characteristics of firms in our sample. The average firm size within our sample is $\$ 21$ billion with a median firm size of $\$ 662$ million. The smaller median figure and the high standard deviation are indicative that the distribution on firm size is highly skewed. The average number of business segments of firms in our sample is four and the average financial leverage (debt-to-equity ratio) is 1.04 and the $\mathrm{M} / \mathrm{B}$ ratio is 3.44 . The median ROA for the sample of firms is $6.62 \%$ and the median stock return is $8.89 \%$. More than $50 \%$ of firms have non-zero accruals with the absolute value of forward-looking discretionary accruals being 0.07 . The average standard deviation of ROA over the last 5 years of firms in our sample is $11.42 \%$, while the figure for standard deviation of sales scaled by total assets is $21.74 \%$.

In Panel $\mathrm{C}$ of Table 2, it can be seen that the average tenure of Australian CFOs is 5.22 years

\footnotetext{
12 "Top CFOs' pay rises 10pc" by S. Durummond and E. Tadros, Australian Financial Review newspaper, 10 December 2012.
} 
(median 4.08). It is evident that Australian CFOs have similar tenure compared with the US counterparts as Indjejikian \& Matejka (2009) report the mean (median) tenure of American CFOs is 5.91 years (4 years) for publicly listed companies. However, our data shows a much higher proportion of CFOs who have a seat on company board of directors than that reported in the US market. There are approximately $43 \%$ of Australian-listed companies who have the CFO as a member of the board of directors. In contrast, this proportion for the US counterparts is only $8.6 \%$ over the period 2004-2007 (Bedard et al. 2014) or $15.1 \%$ in the years $1993-2006$ (Balsam et al. 2012). Australian CFOs, on average, hold $0.19 \%$ of company shares, a lower level of stock ownership compared with Australian CEOs who hold 4.48\% (Bugeja et al. 2012). The average Australian board size is eight with the majority of board members (60\%) being non-executive directors.

\section{CFO compensation - Empirical analysis}

In this section we investigate the extent to which the incentive alignment theory and the managerial power theory explain the level of CFO compensation. Table 3 presents the regression results for different types of $\mathrm{CFO}$ compensation when compensation data is expressed in dollar value. In Panel A of Table 3, we show the OLS results of the first group (Salary, Total cash comp, and Total comp). For the second group (Bonus and Total non-cash comp) depicted in Panel B, the results of both OLS and tobit regression are presented as this group contains a number of zero-value observations.

[Insert Table 3]

Overall, the results in Table 3 are similar across all compensation specifications. In both panels of Table 3, the coefficient of the Firm Size variable is significantly positive across all compensation components, implying that larger firms tend to pay higher compensation to their CFOs. Our result is consistent with the recent US studies on CFO compensation (Indjejikian \& Matejka 2009, Bedard et al. 2014) that larger firms demand higher quality CFOs and are prepared to pay for such quality. Similar to Balsam et al. (2012), the Bus. Segments variable is positive and significantly associated with two types of compensation, namely, Bonus and Total cash comp. This result would indicate that the business complexity, as measured by the number of business segments, affects the cash compensation component. Our results suggest that there is evidence supporting the traditional view that CFO compensation is linked to the level of job complexity. 
As mentioned earlier in Section 3.1, designing executive remuneration packages to align managerial incentives to shareholders' benefits requires observable measures of firm's profitability. In the analysis of the two firm performance proxies (ROA and Stock Returns), only the Stock Returns variable is found to be significantly positive with all CFO compensation components, except the case of Salary where no significant relationship is found. ${ }^{13}$ Our finding of a positive association between CFO compensation and stock performance measure is also evident in a number of US studies (Balsam et al. 2012, Hoitash et al. 2012, Bedard et al. 2014). This finding is also consistent with internationally empirical research on CEO compensation (e.g. Core et al. 1999, Kato et al. 2007, Unite et al. 2008, Bugeja et al. 2012) that executive remuneration is aligned with firm stock market performance. For the measure of CFO-specific performance, the Discret. Accruals variable, we do not find the pay-for-performance link as the coefficient of this variable is insignificant across all types of CFO compensation. This suggests that Australian CFO compensation is not related to the performance measure of accruals quality that is specifically attributed to CFOs. In summary, we find supporting evidence for the traditional view when performance is measured at firm level. When the performance is measured at the CFO-specific level, the traditional view is not supported.

Consistent with the predictions of the rent extraction theory, four of the five managerial power variables (CFO Board, CFO Ownership, CFO Tenure and Board Size) are found to be positive and significantly related to CFO compensation. The Insider Ratio is the only managerial power variable that is found to be not significant. The lack of significance between the Insider Ratio variable and $\mathrm{CFO}$ compensation is also evident in some of previous research on CEO compensation (Core et al. 1999, Gristein \& Hribar 2004, Chalmers et al. 2006, Bugeja et al. 2012, Guthrie et al. 2012).

Among the four significant managerial power proxies, the CFO Board variable has the most significant impact on Australian CFO remuneration. ${ }^{14}$ Indeed, with the exception of the Bonus component, the $C F O$ Board variable is found to be significantly positive in all compensation types. This indicates that CFOs who sit on the company board of directors receive higher com-

\footnotetext{
${ }^{13}$ In our regression analysis, the firm performance variable $R O A_{t}$ is insignificant in all specifications. We replace $R O A_{t}$ by the lagged performance variable $R O A_{t_{1}}$ to examine whether the deferred pay of cash bonus attenuates the link between pay and contemporaneous performance. The results are similar to those reported in Table 3; $R O A_{t_{1}}$ is still not a significant variable. We also use the lagged performance variable, Stock Returns at time t-1, in the regression and the results are robust.

${ }^{14}$ As presented in Table 3, except for the case of Bonus component, the coefficient estimates of the CFO Board variable are highest among the managerial power proxies, ranging from 114.16 to 323.59 and their corresponding $t$-statistics are from 1.97 to 7.05 .
} 
pensation than CFOs who do not sit on the board. The significance of the CFO Board variable is also reported in recent US research on CFO compensation (Balsam et al. 2012, Bedard et al. 2014). To gain further understanding of the CFO Board variable, we divide the original sample into two sub-samples: the first consists of 242 observations in which the CFO is a member of the company board while the second sub-sample consists of 321 observations in which the CFO does not have a seat on the board. Table 4 presents descriptive statistics for each compensation component of the two sub-samples as well as test statistics on examining the difference in the mean and median of those sub-samples. The major inference from Table 4 is that CFOs who serve on their company board earn significantly more than other CFOs for all types of compensation. For example, CFOs who have a seat on company board of directors are on average rewarded for total compensation of $\$ 1.4$ million. This figure is approximately $\$ 969,000$ for CFOs who do not have board membership. An additional analysis ${ }^{15}$ shows that the difference in compensation of firms in the two sub-samples is not affected by company size as firms in these sub-samples are similar in size, measured as company book assets in prior year. The test statistics for the difference in mean and median of company book assets of the two sub-samples are not statistically significant at the conventional levels.

[Insert Table 4]

Similar to the findings on the CFO Board variable, the significantly positive signs of the coefficients of the CFO Ownership, CFO Tenure and Board Size variables (see Table 3) support the predictions of the managerial power approach. Finkelstein \& Hambrick (1989) argue that substantial stock ownership gives CEOs more control over their pay and increases the possibility of entrenchment. We also find that CFOs with higher level of company stock ownership are rewarded more, with the exception of bonus payments. In addition, Hermalin \& Weisbach (1998) and Ryan \& Wiggins (2004) find that CEOs become more entrenched and gain greater managerial power over the board of directors as their tenure increases. Our results show that the longer the CFOs are in power, the more entrenched they become which results in higher remuneration in Bonus and Total cash comp. This is consistent with the finding of a positive relationship between CFO tenure and CFO bonus by Indjejikian \& Matejka (2009). Our finding on the Board Size variable which is significantly positive with three types of CFO compensation: Salary, Total non-cash comp and Total comp is consistent with previous research on CEO compensation (Yermack 1996, Core et al. 1999, Bugeja et al. 2012). In general, smaller boards are likely to be more effective and the difficulty of monitoring increases with board size.

\footnotetext{
${ }^{15}$ For brevity, the analysis on the difference in company size between the two sub-samples is not reported. Results are available upon request.
} 
Within the literature there has been a number of interpretations of the three proxies for managerial power (CFO Board, CFO Tenure and CFO Ownership). They can be used as measures for either the traditional view or the rent extraction theory. For example, if a CFO has a seat on the board, they can vote on many important issues such as director pay and director nomination. This creates interdependency and is similar to the interdependency created when the CEO chairs the board meeting (Bedard et al. 2014). Alternatively, by having a seat on the board of directors, the CFO will be able to share more relevant financial information to other board members and this potentially could help the board in its advisory role (Adams \& Ferreira 2007). Similarly, as a CFO's tenure with the firm increases, they are likely to become more entrenched and will have greater managerial power over the board of directors (Hermalin \& Weisbach 1998, Ryan \& Wiggins 2004). On the other hand, when the CFO stays longer in the firm, the board has a greater opportunity to assess the value adding contribution of the CFO and impact on firm performance. In interpreting equity levels, substantial stock ownership can provide managers with more control over their pay and thereby increases the possibility of entrenchment (Morck et al. 1988, Finkelstein \& Hambrick 1989). Alternatively, executive shareholdings at an optimal level can reduce agency costs arising from the separation of ownership and control (Jensen \& Meckling 1976). Therefore, a positive relationship between CFO compensation and our three measures of managerial power could be expected under both the incentive alignment and the rent extraction approach. It is common in the CEO compensation literature that CEO tenure, CEO ownership and CEO duality are used as proxies for executive entrenchment (e.g. Gristein \& Hribar 2004, Adams et al. 2005, Bugeja et al. 2012) and this has been the approach used in our study.

For the control variables, firm leverage (Leverage) is found to be significantly negative with Salary and Total cash comp components. One possible interpretation is the degree of lender monitoring, that is, lenders are likely to monitor highly levered firms more closely. Therefore, for highly levered firms, they are less likely to offer excessive executive compensation packages. This finding is consistent with a lender having an expectation that higher company leverage is associated with lower $\mathrm{CFO}$ compensation. With the $M / B$ Ratio variable, our results show a highly positive relationship with all compensation components which indicate that high growth firms tend to award higher compensation to their CFOs. This finding is consistent with previous studies of CFO compensation in the US (Balsam et al. 2012, Bedard et al. 2014). For the firm risk attribute, there is a positive association with CFO compensation in the Std $\operatorname{dev}(R O A)$ 
variable. The relationship is significant for both Total cash comp. and Total comp. components and implies that riskier firms are more likely to provide higher rewards to CFOs, but not with non-cash compensation.

To further understand the economic significance of our regression results, we examine the magnitude of the statistically significant coefficients of those variables representing the incentive alignment approach and the managerial variable approach. As can be seen from Panel A of Table 3, an increase of $\$ 1$ million in company book assets increases the CFO total compensation by $\$ 4.82$ million. Likewise, an increase in company stock returns of $1 \%$ is associated with an increase of $\$ 221,200$ in CFO total pay. In addition, a CFO who has a seat on the company board of directors receives on average $\$ 323,590$ more in total compensation than a CFO who does not sit on the board. Furthermore, an increase of $1 \%$ in CFO equity ownership contributes an additional amount of $\$ 135,970$ in CFO total remuneration. Finally, if the size of the company board of directors is increased by one member, the CFO's total pay is increased by $\$ 100,180$.

Overall, our results indicate that the most economically significant factors that determine Australian CFO compensation are measures of job complexity, firm stock market performance and measures of managerial power. The findings are consistent with both the incentive alignment and rent extraction approach. However, the insignificance of the CFO-specific performance measure (i.e. Discret. Accruals variable) does not support the incentive alignment approach.

The analysis presented in Table 3 contains a number of variables that are right skewed (all CFO compensation and CFO Ownership variables (see statistics in Table 2)). To mitigate the problem we conduct additional testing and transform the variables using logarithmic scales. Table 5 presents the results of the analysis of the transformed variables. The results in Table 5 are similar to those in Table 3 but with a more significant finding for the CFO Board variable. The positive association between $\mathrm{CFO}$ compensation and CFO Board variable is statistically significant across all types of CFO compensation which supports the rent extraction theory. However, the Discret. Accruals variable gives contradictory evidence to the incentive alignment approach as it is significantly positive under the category of Total non-cash comp. This implies that CFOs with lower firm reporting quality are compensated more with stocks and options. This finding is similar to what found by Chalmers et al. (2006) that Australian CEOs are able extract rent through options compensation. For the economic control variables, $M / B$ Ratio is the only significantly positive measure in the Total non-cash comp component. This finding may suggest 
that high growth opportunity firms have less liquidity relative to lower growth opportunity firms and are more inclined to use shares to compensate their CFOs.

[Insert Table 5]

It is understandable that accruals management is one of the most important discretionary tools available to managers to temporarily boost or reduce their firm's reported earnings. Recent research has shown that CFO's influence on company earnings management can be stronger than that of CEO. Jiang et al. (2010) find that the magnitudes of accruals are significantly more increasing in CFO equity incentives than in CEO equity incentives. Sharing the same view, Chava \& Purnanandam (2010) argue that CFOs risk-preferences, not CEO's, affect corporate accrual decisions in significant ways. Relatedly, Dejong \& Ling (2013) document that CFOs exert a larger influence on abnormal accruals than CEOs after controlling for firm policy decisions. Therefore it is relevant to have discretionary accruals to proxy for CFO-specific performance and use the link between CFO pay and abnormal accruals in judging the validity of the interest alignment view.

The information and findings presented in Table 3 and 5 show that both the incentive alignment theory and the managerial power theory have explanatory power in determining Australian CFO compensation. The significantly positive association between measures of job complexity (Firm Size and Bus. Segment variables) and CFO compensation provides support for the incentive alignment hypothesis. In addition, our findings indicate that CFO compensation is influenced by company stock market performance and this result is consistent with the alignment incentive view. In contrast to the predictions of the incentive alignment approach, we find no evidence on the relationship between CFO compensation and a measure of performance that is specifically linked to CFOs. The coefficient of the Discret. Accruals variable is not significant when compensation is measured in dollar value but positively significant under the Total non-cash comp type when compensation is in logarithmic scale. This finding would indicate that CFOs in lower reporting quality firms are rewarded with more stocks and options, and to that extent this finding is consistent with the managerial power argument. For the managerial power variables (i.e. CFO Board, CFO Ownership, CFO Tenure and Board Size), all their coefficient estimates are significantly positive with the exception of the Insider Ratio variable. This provides strong support for the argument that managerial power enables the extraction of rent by powerful CFOs. Furthermore, the set of managerial power variables are economically significant in explaining the variation of CFO remuneration. Overall, our results would indicate that Australian CFO 
compensation is determined more by the level of CFO managerial power as the results are not consistent across all the variables for the incentive alignment theory.

\subsection{Additional analyses}

\subsubsection{Global Financial Crisis (GFC) effect}

In order to investigate the effect of the GFC on CFO compensation, we replace the fixed time effect by a variable, After $G F C$, to control for the pre and post-GFC periods in the regression (1). This variable has an indicator equal to one if the year of assessing CFO compensation is after the GFC, that is, 2009 and 2010. We find that the CFO bonus is significantly lower (at the $1 \%$ level) in the years following the GFC. However, the reduction of the CFO bonus is offset by the increase in CFO salary which makes their total compensation commensurate with the pre-GFC period.

\subsubsection{Industry-adjusted stock returns}

In Table 3 and Table 5, the company's annual common stock return is used to proxy for company market performance. As a robust test we replace the unadjusted return by the industry-adjusted return where industry returns are based on the returns on GICS sectors from the S\&P/ASX 200 index. ${ }^{16}$ Under the incentive alignment approach, it is expected that CFOs will be rewarded for higher remuneration if their firm performance is above that of the industry performance. The regression results for the industry-adjusted returns yields coefficient estimates similar to those shown in Table 3 and Table 5 and supports the above commentary.

\subsubsection{Alternative accrual model}

To estimate discretionary accruals, we use the forward-looking Jones model developed by Dechow et al. (2003). This model is widely-used and is one of many models that could be applied to estimate abnormal accruals. We therefore test whether our results still hold when using alternative approaches to estimate discretionary accruals. Specifically, we use the margin model developed by Peasnell et al. (2000) and we find that our results are robust to this model.

\footnotetext{
${ }^{16}$ The returns on all 10 GICS industries (i.e. Consumer Discretionary, Consumer Stables, Energy, Financials, Health Care, Industrials, Information Technology, Materials, Telecommunication Services, and Utilities) are obtained from S\&P Dow Jones Indices website and search for the relevant index (http://au.spindices.com/indices/equity/sp-asx-200-consumer-discretionary-sector).
} 


\subsubsection{Real earnings management}

Our analysis is based on the discretionary accruals to measure CFO-specific performance. In addition to accrual-based manipulation, firms can also manage earnings by altering real activities (Graham et al. 2005, Roychowdhury 2006, Cohen et al. 2008). As a robust test, we replace the proxy of discretionary accruals in the regression (1) by a variable that captures the effects of real earnings management using the methods of Roychowdhury (2006). Roychowdhury (2006) investigates the manipulation of cash flows from operations $(\mathrm{CF})$, discretionary expenditures (the sum of R\&D, advertising, general and administrative (SG\&A) expenses) and production costs (the sum of cost of goods sold (COGS) and change in inventory). Due to data unavailability on COGS and discretionary expenses on DatAnalysis database, ${ }^{17}$ we exam the manipulation of real activities on CF and capital expenditures (CAPEX) since firms can reduce reported expenses and increase earnings by reducing capital expenditures. Following Roychowdhury (2006), the normal level of CF and CAPEX are estimated for each industry and year using the following equations:

$$
\begin{gathered}
C F_{t} / T A_{t-1}=\alpha_{0}+\alpha_{1}\left(1 / T A_{t-1}\right)+\alpha_{2}\left(\text { Sales }_{t} / T A_{t-1}\right)+\alpha_{3}\left(\Delta \text { Sales }_{t} / T A_{t-1}\right)+\epsilon_{t} \\
C A P E X_{t} / T A_{t-1}=\alpha_{0}+\alpha_{1}\left(1 / T A_{t-1}\right)+\alpha_{2}\left(\text { Sales }_{t-1} / T A_{t-1}\right)+\epsilon_{t}
\end{gathered}
$$

where $T A_{t-1}$ is the total assets at the end of period $t-1, \Delta$ Sales $_{t}=$ Sales $_{t}-$ Sales $_{t-1}$

The abnormal CF and abnormal CAPEX are measured as the estimated residual from the regression (2) and (3), respectively. Consistent with recent research by Cohen \& Zarowin (2010) and Zang (2012), we aggregate the abnormal CF and abnormal CAPEX into one measure, REM, to capture the total effects of real earnings management. We take the absolute value of $R E M$ and the higher this amount the more likely that the firm is engaging in manipulations of sales and capital expenditures. The firm $\mathrm{CFO}$ will consequently receive lower remuneration under the incentive alignment perspective. In the other words, under the traditional view there would be a negative relationship between CFO compensation and our measure of real earnings management, REM.

We replicate the regressions of Table 3 and Table 5 with the proxy of real earnings management, the absolute value of $R E M$, instead of the discretionary accruals variable. It is found that the co-

\footnotetext{
${ }^{17}$ DatAnalysis do not report figures on COGS, R\&D expenses and advertising expenses separately for Australian companies.
} 
efficient of the $R E M$ variable is significantly positive with the logarithmic measures of Total cash compensation and Total compensation. ${ }^{18}$ This implies that firms engaging in manipulating real activities reward their CFOs higher compensation, contrast to the incentive alignment approach. It also indicates that our results are robust to different measures of earnings management.

\section{Conclusion}

As intimated by Copeland et al. (2005), the role of the CFO has become significantly more complex with the onset of globalization and new and rapidly changing business models. It is now widely recognized that the $\mathrm{CFO}$ is a strategic decision maker, as such, the $\mathrm{CFO}$ role and the effectiveness of this role have become the subject of stakeholder awareness and scrutiny. This enhanced awareness together with heightened reporting requirements on remuneration makes it timely to further contribute our understanding of the linkages between CFO characteristics, remuneration and performance. In this paper, we provide insights to the determinants of CFO compensation in Australia by investigating the explanatory power of the incentive alignment and managerial power theory. We conduct our analysis based on a sample of 563 exchangelisted firms on the ASX from 2006 to 2010. We find that measures of job complexity and firm-overall performance are positively related to the level of CFO compensation. However, we do not find the significant association between CFO remuneration and a measure of CFOspecific performance, proxied as the absolute value of discretionary accruals. The coefficient of the discretionary accruals variable is significantly positive for the non-cash component of $\mathrm{CFO}$ remuneration, indicating a divergence from the traditional view. CFOs appear to be able to extract rent through higher non-cash remuneration when they deliver a lower level of reporting quality.

Four measures of our managerial power (CFO Board, CFO Ownership, CFO Tenure and Board Size) play a significant role in determining CFO compensation which provides strong support to the managerial power approach. The managerial power variables appear to explain more variation in CFO remuneration than measures of job complexity and performance. Relatively, our results support the managerial power theory more and CFO power is a significant driver of CFO compensation.

\footnotetext{
${ }^{18}$ The results are robust when the proxy of real earnings management is changed from the aggregated measure, $R E M$, to the individual meausres, i.e. the absolute value of the abnormal CF or the abnormal CAPEX.
} 


\section{Acknowledgement}

The authors would like to acknowledge the Accounting and Finance Association of Australia and New Zealand (AFFANZ) and Curtin Business School for research grants to support this project. We are grateful for the insightful comments of Sue Wright, Zoltan Matolcsy, Michael Jones, Martin Bugeja and delegates at the 2014 British Accounting and Finance Association conference. The research assistance provided by Shaun Singh and Hanh Tran is also acknowledged. 


\section{References}

Adams, R., Almeida, H. \& Derreira, D. (2005), 'Powerful CEOs and Their Impact on Corporate Performance', The Review of Financial Studies 18(4), 1403-1432.

Adams, R. \& Ferreira, D. (2007), 'A Theory of Friendly Boards', The Journal of Finance 62(1), 217-250.

Agarwal, N. C. (1981), 'Determinants of Executive Compensation', Industrial Relations 20(1), 36-45.

Balsam, S., Gordon, E. A. \& Li, X. (2015), 'Mandatory Disclosure Reform, Monitoring and Executive Compensation', Available at SSRN: http://ssrn.com/abstract=2013653 .

Balsam, S., Irani, A. J. \& Yin, Q. J. (2012), 'Impact of Job Complexity and Performance on CFO Compensation', Accounting Horizons 26(3), 395-416.

Balsam, S., Jiang, W. \& Lu, B. (2014), 'Equity Incentives and Internal Control Weaknesses', Contemporary Accounting Research 31(1), 178-201.

Bebchuk, L. A. \& Fried, J. M. (2003), 'Executive Compensation as an Agency Problem', Journal of Economic Perspectives 17(1), 71-92.

Bebchuk, L. A., Fried, J. M. \& Walker, D. I. (2002), 'Managerial Power and Rent Extraction in the Design of Executive Compensation', The University of Chicago Law Review 69(3), 751846 .

Bebchuk, L. \& Fried, J. (2004), Pay without Performance: The Unfulfilled Promise of Executive Compensation, Harvard University Press, MA.

Bedard, J. C., Hoitash, R. \& Hoitash, U. (2014), 'Chief Financial Officers as Inside Directors', Contemporary Accounting Research 31(3), 787-817.

Bugeja, M., da Silva Rosa, R., Duong, L. \& Izan, H. (2012), 'CEO Compensation from M\&As in Australia', Journal of Business Finance \&J Accounting 39(9), 1298-1329.

Chalmers, K., Koh, P. \& Stapledon, G. (2006), 'The Determinants of CEO Compensation: Rent Extraction or Labour Demand?', The British Accounting Review 38(3), 259-275.

Chava, S. \& Purnanandam, A. (2010), 'CEOs versus CFOs: Incentives and Corporate Policies', Journal of Financial Economics 97(2), 263-278.

Coakley, J. \& Iliopoulou, S. (2006), 'Bidder CEO and Other Executive Compensation in UK M\&As', European Financial Management 12(4), 609-631.

Cohen, D. A., Dey, A. \& Lys, T. Z. (2008), 'Real and Accrual Based Earnings Management in the Pre and Post Sarbanes Oxley Periods', The Accounting Review 83(3), 757-787.

Cohen, D. A. \& Zarowin, P. (2010), 'Accrual-based and Real Earnings Management Activities around Seasoned Equity Offerings', Journal of Accounting and Economics 50(1), 2-19.

Collins, D., Reitenga, A. L. \& Sanchez, J. M. (2008), 'The Impact of Accounting Restatements on CFO Turnover and Bonus Compensation', Advances in Accounting 24(2), 162-171.

Copeland, T. E., Weston, J. F. \& Shastri, K. (2005), Financial Theory and Corporate Policies, Pearson Addison Wesley. 
Core, J. E., Holthausen, R. W. \& Larcker, D. F. (1999), 'Corporate Governance, CEO Compensation, and Firm Performance', Journal of Financial Economics 51(3), 371-406.

Dechow, P. M., Richardson, S. A. \& Tuna, I. (2003), 'Why Are Earnings Kinky? An Examination of the Earnings Management Explanation', Review of Accounting Studies 8(2-3), 355-384.

DeFond, M. L. \& Park, C. W. (2001), 'The Reversal of Abnormal Accruals and The Market Valuation of Earnings Surprises', The Accounting Review 76(3), 374-404.

Dejong, D. \& Ling, Z. (2013), 'Managers: Their Effects on Accruals and Firm Policies', Journal of Business Finance 83 Accounting 40(2), 82-114.

Denis, D., Denis, D. \& Sarin, A. (1997), 'Agency Problems, Equity Ownership, and Corporate Diversification', Journal of Finance 52(1), 135-160.

Ferreira, N., Matos, P. \& Murphy, K. J. (2013), 'Are U.S. CEOs Paid More? New International Evidence', The Review of Financial Studies 26(2), 323-367.

Finkelstein, S. (1992), 'Power in Top Management Team: Dimension, Measurement and Validation', The Academy of Management Journal 35(3), 505-538.

Finkelstein, S. \& Hambrick, D. C. (1989), 'Chief Executive Compensation: A Study of the Intersection of Markets and Political Process', Strategic Management Journal 10(2), 121-134.

Francis, J., Nanda, D. \& Olsson, P. (2008), 'Voluntary Disclosure, Earnings Quality, and Cost of Capital', Journal of Accounting Research 46(1), 53-99.

Ge, W., Matsumoto, D. \& Zhang, J. L. (2011), 'Do CFOs Have Style? An Empirical Investigation of the Effect of Individual CFOs on Accounting Practices', Contemporary Accounting Research 28(4), 1141-1179.

Geiger, M. \& North, D. (2006), 'Does Hiring a New CFO Change Things? An Investigation of Changes in Discretionary Accruals', The Accounting Review 81(4), 781-809.

Gore, A. K., Matsunaga, S. \& Yeung, P. E. (2011), 'The Role of Technical Expertise in Firm Governance Structure: Evidence from Chief Finance Officer Contractual Incentives', Strategic Management Journal 32(7), 771-786.

Graham, J. R., Harvey, C. R. \& Rajgopal, S. (2005), 'The Economic Implications of Corporate Financial Reporting', Journal of Accounting and Economics 40(1), 3-73.

Gristein, Y. \& Hribar, P. (2004), 'CEO Compensation and Incentives: Evidence from M\&A Bonuses', Journal of Financial Economics 73(1), 119-143.

Grossman, S. \& Hart, O. (1983), 'An Analysis of the Principal Agent Problem', Econometrica $\mathbf{5 1}(1), 7-45$.

Guthrie, K., Sokolowsky, J. \& Wan, K. (2012), 'CEO Compensation and Board Structure Revisited', The Journal of Finance 67(3), 1149-1168.

Haugen, R. A. \& Senbet, L. W. (1981), 'Resolving the Agency Problems of External Capital through Options', The Journal of Finance 36(3), 629-647.

Heibl, M. R. W., Neubauer, H. \& Duller, C. (2013), 'The Chief Financial Officer's Role in Medium-sized Firms: Exploratory Evidence from Germany', Journal of International Business Ef Economics 13(2), 83-92. 
Hermalin, B. E. \& Weisbach, M. S. (1998), 'Endogenously Chosen Boards of Directors and their Monitoring of the CEO', American Economic Review 88(1), 96-118.

Hoitash, R., Hoitash, U. \& Johnstone, M. (2012), 'Internal Control Material Weakness and CFO Compensation', Contemporary Accounting Research 29(3), 768-803.

Indjejikian, R. \& Matejka, M. (2009), 'CFO Fiduciary Responsibilities and Annual Bonus Incentives', Journal of Accounting Research 47(4), 1061-1093.

Jensen, M. C. \& Meckling, W. H. (1976), 'Theory of the Firm: Managerial Behaviour, Agency Costs and Ownership Structure', Journal of Financial Economics 3(4), 305-360.

Jensen, M. C. \& Murphy, K. J. (1990), 'Performance Pay and Top Management Incentives', Journal of Political Economy 98(2), 225-265.

Jiang, J. X., Petroni, K. R. \& Wang, I. Y. (2010), 'CFOs and CEOs: Who Have the Most Influence on Earnings Management', Journal of Financial Economics 96(3), 513-526.

Jones, J. (1991), 'Earnings Management During Import Relief Investigations', Journal of Accounting Research 29(2), 193-228.

Kato, T., Kim, W. \& Lee, J. H. (2007), 'Executive Compensation, Firm Performance, and Chaebols in Korea: Evidence from New Panel Data', Pacific-Basin Finance Journal 15(1), 3655.

Kiel, G. C. \& Nicholson, G. J. (2003), 'Board Composition and Corporate Performance: How the Australian Experience Informs Contrasting Theories of Corporate Governance', Corporate Governance: An International Review 11(3), 189-205.

Loyeung, A. \& Matolcsy, Z. (2015), 'CFO's Accounting Talent, Compensation and Turnover', Accounting and Finance (Forthcoming).

McConnell, J. J. \& Servaes, H. (1990), 'Additional Evidence on Equity Ownership and Corporate Value', Journal of Financial Economics 27(2), 595-612.

Mirrlees, J. (1976), 'The Optimal Structure of Incentives and Authority within an Organisation', Bell Journal of Economics 7(1), 105-131.

Morck, R., Shleifer, A. \& Vishny, R. W. (1988), 'Managerial Ownership and Market Valuation: An Empirical Analysis', Journal of Financial Economics 20(1), 293-315.

Morse, A., Nanda, V. \& Seru, A. (2011), 'Are Incentive Contracts Rigged by Powerful CEOs?', The Journal of Finance 66(5), 1779-1821.

Murphy, K. J. (2013), 'Executive Compensation: Where We Are and How We Got There', Handbook of Economics and Finance (edited by G. Constantinides, M. Harris and R. Stulz) Chapter 4, 211-356. Elsevier Science North Holland.

Ozkan, N. (2011), 'CEO Compensation and Firm Performance: An Empirical Investigation of UK Panel Data', European Financial Management 17(2), 260-285.

Peasnell, K., Pope, P. \& Young, S. (2000), 'Detecting Earnings Management Using Crosssectional Abnormal Accruals Model', Accounting and Business Research 30(4), 313-326.

Rose, N. \& Shepard, A. (1997), 'Firm Diversification and CEO Compensation: Managerial Ability or Executive Entrenchment?', Rand Journal of Economics 28(3), 489-514. 
Rosenstein, S. \& Wyatt, J. G. (1990), 'Outside Directors, Board Independence, and Shareholder Wealth', Journal of Financial Economics 26(2), 175-191.

Roychowdhury, S. (2006), 'Earnings Management through Real Activities Manipulations', Journal of Accounting and Economics 42(3), 335-370.

Ryan, H. E. \& Wiggins, R. A. (2004), 'Who is in Whose Pockets? Director Compensation, Board Independence, and Barriers to Effective Monitoring', Journal of Financial Economics 73(3), 497-524.

Schultz, E., Tian, G. Y. \& Twite, G. (2013), 'Corporate Governance and the CEO PayPerformance Link: Australian Evidence', International Review of Finance 13(4), 447-472.

Smith, C. W. \& Watts, R. L. (1992), 'The Investment Opportunity Set and Corporate Financing, Dividend, and Compensation Policies', Journal of Financial Economics 32(3), 263-292.

Unite, A. A., Sullivan, M. J., Brookman, J., Majadillas, M. A. \& Taningco, A. (2008), 'Executive Pay and Performance in the Phillippines', Pacific-Basin Finance Journal 16(5), 606-623.

Wang, W., Shin, Y. \& Francis, B. B. (2012), 'Are CFOs' Trades More Informative Than CEOs' Trades?', Journal of Financial and Quantitative Analysis 47(4), 743-762.

Wang, X. (2010), 'Increased Disclosure Requirements and Corporate Governance Decisions: Evidence from Chief Financial Officers in the Pre- and Post-Sarbanes-Oxley Periods', Journal of Accounting Research 48(4), 885-920.

White, H. (1980), 'A Heteroscedasticity Consistent Covariance Matrix Estimator and a Direct Test of Heteroscedasticity', Econometrica 48(4), 817-838.

Yermack, D. (1996), 'Higher Market Valuation of Companies with a Small Board of Directors', Journal of Financial Economics 40(1), 185-211.

Zamora, V. L. (2009), 'Do Managers Benefit from Superior Forecasting', Available at SSRN: http://ssrn.com/abstract $=1324204$.

Zang, A. Y. (2012), 'Evidence on the Trade-Off between Real Activities Manipulations and Accrual-Based Earnings Management', The Accounting Review 87(2), 675-703.

Zorn, D. M. (2004), 'Here a Chief, There a Chief: The Rise of the CFO in the American Firm', American Sociological Review 69(3), 245-364. 
Table 1: Variable definitions

Variables

Definition

Sources

of data

\section{CFO compensation}

Salary

Bonus

Total cash comp

Total non-cash comp

Total comp
The sum of salary and superannuation paid to the CFO during the year

Bonus paid to the CFO in the year

The sum of salary, bonus and other cash compensation paid to the $\mathrm{CFO}$

Total value of restricted stock rewards and stock options awards granted to the $\mathrm{CFO}$ as part of their remuneration package

The CFO total compensation, calculated as the sum of cash and non-cash compensation
Capital $I Q$

Capital $I Q$

Capital $I Q$

Capital $I Q$

Capital $I Q$

\section{Financial characteristics}

Firm Size

Bus. Segments

$R O A$

Stock Returns

Discret. Accruals

Leverage $M / B$ Ratio

Std dev (ROA)

Std dev (Sales/TA)
The book value of total assets in the prior year

The number of business segments of firm

Earnings before tax divided by total assets

The unadjusted return on company's shares during the year, calculated as the current year share price divided by the previous year share price, expressed in natural logarithm

The absolute value of the difference between total accruals (measured as the difference between firm earnings and operating cash flows, scaled by total assets in previous year) and estimated forward-looking non-discretionary accruals from the modified Jones model developed by Dechow et al. (2003)

Total debt divided by the market value of equity

The market value of equity divided by the book value of equity

Standard deviation of ROA over the last 5 years

Standard deviation of the ratio of sales divided by total assets over the last 5 years
FinAnalysis FinAnalysis \& Capital $I Q$

FinAnalysis

FinAnalysis

FinAnalysis

FinAnalysis FinAnalysis FinAnalysis FinAnalysis

\section{Governance and CFO characteristics}

CFO Board

CFO Ownership CFO Tenure

Board Size

Insider Ratio
A binary variable coded as one if the CFO is on the company board of directors, zero otherwise

The percentage of company shares owned by the CFO

The number of years since the CFO was appointed

The number of directors on the board of directors

The percentage of executive directors on the board
Capital $I Q$

database, Boardroom database and company annual reports 
Table 2: Descriptive statistics

Mean Median Standard deviation

Panel A: CFO compensation (\$)

$\begin{array}{lccc}\text { Salary } & 473,877 & 371,255 & 300,533 \\ \text { Bonus } & 281,164 & 100,000 & 460,228 \\ \text { Total cash comp } & 896,489 & 540,410 & 966,429 \\ \text { Total non-cash comp } & 259,373 & 82,879 & 555,875 \\ \text { Total comp } & 1,155,862 & 691,293 & 1,309,042\end{array}$

Panel B: Financial characteristics

$\begin{array}{lccc}\text { Firm Size (\$mil) } & 20,815 & 662 & 84,031 \\ \text { Bus. Segment } & 3.99 & 4.00 & 2.47 \\ \text { Leverage } & 1.04 & 0.44 & 2.15 \\ \text { M/B Ratio } & 3.44 & 2.29 & 4.50 \\ \text { ROA } & 4.16 \% & 6.62 \% & 18.20 \% \\ \text { Stock Returns } & 7.93 \% & 8.89 \% & 58.77 \% \\ \text { Discret. Accruals } & 0.60 & 0.07 & 5.09 \\ \text { Std dev (ROA) } & 11.42 \% & 3.00 \% & 45.38 \% \\ \text { Std dev (Sales/TA) } & 21.74 \% & 12.53 \% & 49.32 \%\end{array}$

\section{Panel C: Governance and CFO characteristics}

\author{
CFO Board \\ CFO Ownership \\ CFO Tenure (years) \\ Board Size \\ Insider Ratio
}

$$
\begin{gathered}
42.98 \% \\
0.19 \% \\
5.22 \\
7.79 \\
39.53 \%
\end{gathered}
$$

$0.03 \%$
4.08
8
$37.50 \%$

$0.62 \%$

3.82

2.59

$15.72 \%$
2.47

$18.20 \%$

$58.77 \%$

$9.32 \%$

This table presents summary statistics of 563 firm-year observations (or 281 unique firms) in our sample for the years 2006 to 2010. CFO compensation is shown separately for Bonus, Salary, Total cash compensation, Total non-cash compensation and Total compensation. Firm Size is book value of total assets in the prior year, expressed in natural logarithm. Bus. Segments is the number of firm's business segments, expressed in logarithmic scale. Leverage is firm financial leverage, calculated as total debt divided by market value of equity. $M / B$ Ratio is market value of equity divided by the book value of equity. $R O A$ is return on assets, calculated as earnings before tax divided by total assets. Stock Returns is raw return on company's shares during the year, calculated as the current year share price divided by the previous year share price, expressed in natural logarithm. Discret. Accruals is the absolute value of forward-looking discretionary accruals from the modified Jones (1991) model, developed by Dechow et al. (2003). Std dev (ROA) is standard deviation of ROA over the last 5 years. Std dev (Sales/TA) is standard deviation of the ratio of sales divided by total assets. CFO Board is a binary variable coded as one if the CFO is on the company board of directors, zero otherwise. CFO Ownership is the percentage of company shares owned by the CFO. CFO Tenure is the number of years since the CFO was appointed, expressed in natural logarithm. Board Size is the number of directors on the board of directors. Insider Ratio is the percentage of executive directors on the board. 
Table 3: Regressions of CFO compensation - when compensation in dollar value (\$'000)

Panel A: Salary, Total cash compensation, and Total compensation (\$'000) - OLS regression

\begin{tabular}{|c|c|c|c|}
\hline & Salary & Total cash compensation & Total compensation \\
\hline & OLS & OLS & OLS \\
\hline Firm Sizet-1 (ln) & $\begin{array}{c}109.73^{* * *} \\
{[17.74]}\end{array}$ & $\begin{array}{c}249.56^{* * *} \\
{[7.24]}\end{array}$ & $\begin{array}{c}348.63^{* * *} \\
{[9.01]}\end{array}$ \\
\hline Bus. Segments (ln) & $\begin{array}{l}10.78 \\
{[1.11]}\end{array}$ & $\begin{array}{c}58.17^{* *} \\
{[2.03]}\end{array}$ & $\begin{array}{l}56.30 \\
{[1.30]}\end{array}$ \\
\hline ROA & $\begin{array}{l}-1.73 \\
{[-0.05]}\end{array}$ & $\begin{array}{r}-112.97 \\
{[-0.91]}\end{array}$ & $\begin{array}{c}-178.24 \\
{[-1.01]}\end{array}$ \\
\hline Stock Returns & $\begin{array}{c}3.55 \\
{[0.29]}\end{array}$ & $\begin{array}{c}131.72^{* * *} \\
{[3.12]}\end{array}$ & $\begin{array}{l}221.20^{* * *} \\
\quad[3.66]\end{array}$ \\
\hline Discret. Accruals & $\begin{array}{c}0.34 \\
{[0.40]}\end{array}$ & $\begin{array}{c}2.46 \\
{[1.39]}\end{array}$ & $\begin{array}{c}2.65 \\
{[0.85]}\end{array}$ \\
\hline CFO Board & $\begin{array}{c}143.42^{* * *} \\
{[7.05]}\end{array}$ & $\begin{array}{l}209.44^{* * *} \\
{[3.09]}\end{array}$ & $\begin{array}{c}323.59^{* * *} \\
{[3.35]}\end{array}$ \\
\hline CFO Ownership & $\begin{array}{c}37.58^{* *} \\
{[2.56]}\end{array}$ & $\begin{array}{c}79.06^{* *} \\
{[2.52]}\end{array}$ & $\begin{array}{c}135.97^{* * *} \\
\quad[2.77]\end{array}$ \\
\hline CFO Tenure (ln) & $\begin{array}{l}-9.81 \\
{[-1.02]}\end{array}$ & $\begin{array}{l}74.40^{*} \\
{[1.78]}\end{array}$ & $\begin{array}{l}43.81 \\
{[0.80]}\end{array}$ \\
\hline Board Size & $\begin{array}{c}12.18^{* *} \\
{[2.01]}\end{array}$ & $\begin{array}{l}52.88 \\
{[1.40]}\end{array}$ & $\begin{array}{c}100.18^{* *} \\
{[2.16]}\end{array}$ \\
\hline Insider Ratio & $\begin{array}{l}-78.69 \\
{[-1.32]}\end{array}$ & $\begin{array}{l}63.66 \\
{[0.30]}\end{array}$ & $\begin{array}{l}249.93 \\
{[0.85]}\end{array}$ \\
\hline Leverage & $\begin{array}{c}-30.86^{* * *} \\
{[-7.47]}\end{array}$ & $\begin{array}{c}-39.83^{*} \\
{[-1.78]}\end{array}$ & $\begin{array}{l}-18.89 \\
{[-0.61]}\end{array}$ \\
\hline M/B Ratio & $\begin{array}{c}4.55^{* * *} \\
{[2.60]}\end{array}$ & $\begin{array}{l}14.58^{*} \\
{[1.95]}\end{array}$ & $\begin{array}{c}\mathbf{2 7 . 1 3}^{* * *} \\
{[2.92]}\end{array}$ \\
\hline Std dev (ROA) & $\begin{array}{l}23.71 \\
{[1.05]}\end{array}$ & $\begin{array}{c}84.81^{* *} \\
{[2.08]}\end{array}$ & $\begin{array}{c}117.80^{*} \\
{[1.82]}\end{array}$ \\
\hline Std dev (Sales/TA) & $\begin{array}{l}-2.19 \\
{[-0.21]}\end{array}$ & $\begin{array}{c}7.57 \\
{[0.22]}\end{array}$ & $\begin{array}{c}4.86 \\
{[0.10]}\end{array}$ \\
\hline $\begin{array}{l}\text { Include fixed effects? } \\
\text { (Industry \& Year) }\end{array}$ & Yes & Yes & Yes \\
\hline Adjusted $R^{2}$ & $74.04 \%$ & $47.21 \%$ & $53.91 \%$ \\
\hline No. of firm-year observations & 563 & 563 & 563 \\
\hline No. of unique firms & 281 & 281 & 281 \\
\hline
\end{tabular}

continued on next page 
continued from previous page

Panel B: Bonus and Total non-cash compensation (\$’000) - OLS and Tobit regression

\begin{tabular}{|c|c|c|c|c|}
\hline & \multicolumn{2}{|c|}{ Bonus } & \multicolumn{2}{|c|}{ Total non-cash compensation } \\
\hline & OLS & Tobit & OLS & Tobit \\
\hline Firm Size $_{t-1}(\ln )$ & $\begin{array}{c}108.12^{* * *} \\
{[7.00]}\end{array}$ & $\begin{array}{c}135.53^{* * *} \\
{[8.47]}\end{array}$ & $\begin{array}{c}\text { 99.07*** } \\
{[7.42]}\end{array}$ & $\begin{array}{c}119.88^{* * *} \\
{[6.22]}\end{array}$ \\
\hline Bus. Segments (ln) & $\begin{array}{c}42.14^{* *} \\
{[2.56]}\end{array}$ & $\begin{array}{l}28.96 \\
{[0.87]}\end{array}$ & $\begin{array}{l}-1.88 \\
{[-0.08]}\end{array}$ & $\begin{array}{l}-25.59 \\
{[-0.64]}\end{array}$ \\
\hline ROA & $\begin{array}{c}-110.23 \\
{[-1.45]}\end{array}$ & $\begin{array}{l}38.95 \\
{[0.30]}\end{array}$ & $\begin{array}{l}-65.27 \\
{[-0.78]}\end{array}$ & $\begin{array}{l}33.10 \\
{[0.23]}\end{array}$ \\
\hline Stock Returns & $\begin{array}{c}87.51^{* * *} \\
{[3.88]}\end{array}$ & $\begin{array}{c}145.68^{* * *} \\
{[3.64]}\end{array}$ & $\begin{array}{c}89.48^{* * *} \\
{[2.69]}\end{array}$ & $\begin{array}{c}107.09^{* *} \\
{[2.32]}\end{array}$ \\
\hline Discret. Accruals & $\begin{array}{c}1.20 \\
{[1.53]}\end{array}$ & $\begin{array}{c}0.83 \\
{[0.20]}\end{array}$ & $\begin{array}{c}0.19 \\
{[0.12]}\end{array}$ & $\begin{array}{c}-0.75 \\
{[-0.15]}\end{array}$ \\
\hline CFO Board & $\begin{array}{l}58.09 \\
{[1.47]}\end{array}$ & $\begin{array}{l}79.14 \\
{[1.56]}\end{array}$ & $\begin{array}{c}114.16^{* *} \\
{[2.05]}\end{array}$ & $\begin{array}{c}119.03^{* *} \\
{[1.97]}\end{array}$ \\
\hline CFO Ownership & $\begin{array}{l}22.48 \\
{[1.39]}\end{array}$ & $\begin{array}{c}-4.71 \\
{[-0.11]}\end{array}$ & $\begin{array}{c}56.91^{* *} \\
{[2.28]}\end{array}$ & $\begin{array}{l}60.61 \\
{[1.28]}\end{array}$ \\
\hline CFO Tenure (ln) & $\begin{array}{l}37.42^{*} \\
{[1.67]}\end{array}$ & $\begin{array}{l}35.19 \\
{[1.26]}\end{array}$ & $\begin{array}{l}-30.60 \\
{[-1.05]}\end{array}$ & $\begin{array}{l}-44.20 \\
{[-1.30]}\end{array}$ \\
\hline Board Size & $\begin{array}{l}-1.07 \\
{[-0.09]}\end{array}$ & $\begin{array}{l}-0.82 \\
{[0.07]}\end{array}$ & $\begin{array}{l}47.30^{*} \\
{[1.72]}\end{array}$ & $\begin{array}{c}54.80^{* * *} \\
{[4.01]}\end{array}$ \\
\hline Insider Ratio & $\begin{array}{l}76.45 \\
{[0.66]}\end{array}$ & $\begin{array}{l}-76.17 \\
{[-0.45]}\end{array}$ & $\begin{array}{c}186.27 \\
{[1.19]}\end{array}$ & $\begin{array}{l}67.80 \\
{[0.34]}\end{array}$ \\
\hline Leverage & $\begin{array}{l}13.75 \\
{[0.70]}\end{array}$ & $\begin{array}{c}3.81 \\
{[0.31]}\end{array}$ & $\begin{array}{l}20.95 \\
{[1.07]}\end{array}$ & $\begin{array}{l}15.97 \\
{[1.09]}\end{array}$ \\
\hline M/B Ratio & $\begin{array}{l}5.73^{*} \\
{[1.76]}\end{array}$ & $\begin{array}{c}3.80 \\
{[0.59]}\end{array}$ & $\begin{array}{c}12.54^{* * *} \\
{[3.01]}\end{array}$ & $\begin{array}{c}15.28^{* *} \\
{[2.04]}\end{array}$ \\
\hline Std dev (ROA) & $\begin{array}{l}28.80 \\
{[1.13]}\end{array}$ & $\begin{array}{l}32.85 \\
{[0.56]}\end{array}$ & $\begin{array}{l}32.99 \\
{[0.99]}\end{array}$ & $\begin{array}{l}11.46 \\
{[0.16]}\end{array}$ \\
\hline Std dev (Sales/TA) & $\begin{array}{l}17.52 \\
{[1.02]}\end{array}$ & $\begin{array}{l}39.20 \\
{[0.99]}\end{array}$ & $\begin{array}{l}-2.71 \\
{[-0.12]}\end{array}$ & $\begin{array}{c}5.40 \\
{[0.11]}\end{array}$ \\
\hline $\begin{array}{l}\text { Include fixed effects? (Industry \& Year) } \\
\text { Adjusted } R^{2}\end{array}$ & $\begin{array}{l}\text { Yes } \\
39.10 \%\end{array}$ & Yes & $\begin{array}{c}\text { Yes } \\
30.29 \%\end{array}$ & Yes \\
\hline No. of zero obervations & & 146 & & 125 \\
\hline No. of non-zero observations & & 417 & & 438 \\
\hline No. of firm-year observations & 563 & 563 & 563 & 563 \\
\hline No. of unique firms & 281 & 281 & 281 & 281 \\
\hline
\end{tabular}

This table presents the regression results on CFO compensation which is expressed in dollar value (\$'000), separately for Bonus, Salary, Total cash compensation, Total non-cash compensation and Total compensation. The sample of 563 observations is from 2006 to 2010. Firm Size is book value of total assets in the prior year, expressed in natural logarithm. Bus. Segments is the number of firm's business segments, expressed in logarithmic scale. Leverage is firm financial leverage, calculated as total debt divided by market value of equity. $M / B$ Ratio is market value of equity divided by the book value of equity. ROA is return on assets, calculated as earnings before tax divided by total assets. Stock Returns is raw return on company's shares during the year, calculated as the current year share price divided by the previous year share price, expressed in natural logarithm. Discret. Accruals is the absolute value of forward-looking discretionary accruals from the modified Jones (1991) model, developed by Dechow et al. (2003). Std dev (ROA) is standard deviation of ROA over the last 5 years. Std dev (Sales/TA) is standard deviation of the ratio of sales divided by total assets. CFO Board is a binary variable coded as one if the CFO is on the company board of directors, zero otherwise. CFO Ownership is the percentage of company shares owned by the CFO. CFO Tenure is the number of years since the CFO was appointed, expressed in natural logarithm. Board Size is the number of directors on the board of directors. Insider Ratio is the percentage of executive directors on the board. Each regression uses White (1980) heteroskedasticity consistent covariance estimates. It also includes industry-specific and year-specific fixed effects to control for systematic differences in compensation across industries and over time. Figures in square brackets are $t$-statistics. Emboldened figures indicate statistical significance at $10 \%$ level or better with $*, * *, * * *$ indicating statistically significant at the $10 \%, 5 \%$ or $1 \%$ level. 
Table 4: CFO compensation, separately by CFO on board firms

\begin{tabular}{|c|c|c|c|c|c|c|c|c|}
\hline & \multicolumn{3}{|c|}{$\begin{array}{c}\text { CFO on Board firms } \\
\mathrm{N}=242\end{array}$} & \multicolumn{3}{|c|}{$\begin{array}{c}\text { CFO not on Board firms } \\
\qquad \mathrm{N}=321\end{array}$} & \multicolumn{2}{|c|}{ Difference in mean/median } \\
\hline & Mean & Median & Std dev & Mean & Median & Std dev & $t$-stat. & Mann-Whitney stat. \\
\hline Salary & 546,773 & 447,654 & 350,178 & 418,922 & 336,870 & 243,384 & $5.11^{* * *}$ & $4.04^{* * *}$ \\
\hline Bonus & 337,145 & 137,381 & 478,370 & 238,961 & 83,433 & 442,144 & $2.52^{* *}$ & $2.37^{* *}$ \\
\hline Total cash comp & $1,085,430$ & 719,261 & $1,209,364$ & 754,048 & 477,626 & 701,049 & $4.08^{* * *}$ & $3.79^{* * *}$ \\
\hline Total non-cash comp & 318,970 & 82,504 & 701,338 & 214,443 & 82,879 & 409,295 & $2.22^{* *}$ & 0.62 \\
\hline Total comp & $1,404,400$ & 821,867 & $1,590,370$ & 968,491 & 589,867 & $1,011,268$ & $3.96^{* * *}$ & $3.47^{* * *}$ \\
\hline
\end{tabular}

This table presents compensation summary statistics of firms in our sample for the years 2006 to 2010. It is reported separately for firms that have CFOs on their board of directors (242 firm-year observations or 75 unique firms) and firms that do not have CFOs on the board (321 firm-year observations or 206 unique firms). Tests for difference in mean and median of each compensation component in the two sub-samples are displayed in the table. Bold figures show that there is a significant difference (at the significance level of $10 \%$ or better) between the two sub-samples with $*, * *, * * *$ indicating statistically significant at the $10 \%, 5 \%$ or $1 \%$ level. 
Table 5: Regressions of CFO compensation - when compensation in natural logarithm

\begin{tabular}{|c|c|c|c|c|c|}
\hline & Salary & $\begin{array}{c}\text { Total cash } \\
\text { compensation }\end{array}$ & $\begin{array}{c}\text { Total } \\
\text { compensation }\end{array}$ & Bonus & $\begin{array}{l}\text { Total non-cash } \\
\text { compensation }\end{array}$ \\
\hline Firm Sizet-1 (ln) & $\begin{array}{l}0.26^{* * *} \\
{[14.07]}\end{array}$ & $\begin{array}{l}0.31^{* * *} \\
{[16.09]}\end{array}$ & $\begin{array}{l}0.34^{* * *} \\
{[16.50]}\end{array}$ & $\begin{array}{c}0.49^{* * *} \\
{[10.02]}\end{array}$ & $\begin{array}{c}0.53^{* * *} \\
{[8.77]}\end{array}$ \\
\hline Bus. Segments (ln) & $\begin{array}{l}0.05^{*} \\
{[1.73]}\end{array}$ & $\begin{array}{l}0.06^{*} \\
{[1.85]}\end{array}$ & $\begin{array}{c}0.03 \\
{[0.85]}\end{array}$ & $\begin{array}{l}0.16^{*} \\
{[1.85]}\end{array}$ & $\begin{array}{c}0.12 \\
{[1.15]}\end{array}$ \\
\hline ROA & $\begin{array}{c}0.16 \\
{[1.07]}\end{array}$ & $\begin{array}{c}0.23 \\
{[1.26]}\end{array}$ & $\begin{array}{c}0.05 \\
{[0.22]}\end{array}$ & $\begin{array}{c}0.07 \\
{[0.24]}\end{array}$ & $\begin{array}{l}-0.89 \\
{[-1.27]}\end{array}$ \\
\hline Stock Returns & $\begin{array}{c}-0.11 \\
{[-1.08]}\end{array}$ & $\begin{array}{c}0.08 \\
{[1.57]}\end{array}$ & $\begin{array}{l}0.11^{*} \\
{[1.78]}\end{array}$ & $\begin{array}{c}0.34^{* * *} \\
{[2.68]}\end{array}$ & $\begin{array}{c}0.03 \\
{[0.26]}\end{array}$ \\
\hline Discret. Accruals & $\begin{array}{c}-0.0002 \\
{[-0.13]}\end{array}$ & $\begin{array}{l}-0.001 \\
{[-0.34]}\end{array}$ & $\begin{array}{l}-0.001 \\
{[-0.13]}\end{array}$ & $\begin{array}{l}0.003 \\
{[0.63]}\end{array}$ & $\begin{array}{l}0.01 * \\
{[1.70]}\end{array}$ \\
\hline CFO Board & $\begin{array}{c}0.22 * * * \\
{[3.26]}\end{array}$ & $\begin{array}{c}0.24^{* * *} \\
{[3.48]}\end{array}$ & $\begin{array}{c}0.24^{* * *} \\
{[3.74]}\end{array}$ & $\begin{array}{c}0.28^{* * *} \\
{[\mathbf{2 . 6 5}]}\end{array}$ & $\begin{array}{l}0.29^{* *} \\
{[2.11]}\end{array}$ \\
\hline CFO Ownership (ln) & $\begin{array}{c}0.04^{* *} \\
{[2.35]}\end{array}$ & $\begin{array}{c}0.04^{* * *} \\
{[2.71]}\end{array}$ & $\begin{array}{c}0.04^{* *} \\
{[2.58]}\end{array}$ & $\begin{array}{c}0.04 \\
{[1.29]}\end{array}$ & $\begin{array}{c}0.12^{* * *} \\
{[2.74]}\end{array}$ \\
\hline CFO Tenure (ln) & $\begin{array}{c}-0.02 \\
{[-0.46]}\end{array}$ & $\begin{array}{c}0.04 \\
{[1.04]}\end{array}$ & $\begin{array}{c}0.01 \\
{[0.24]}\end{array}$ & $\begin{array}{c}0.03 \\
{[0.45]}\end{array}$ & $\begin{array}{l}-0.09 \\
{[-0.97]}\end{array}$ \\
\hline Board Size & $\begin{array}{l}0.001 \\
{[0.08]}\end{array}$ & $\begin{array}{c}0.01 \\
{[0.75]}\end{array}$ & $\begin{array}{c}0.02 \\
{[1.12]}\end{array}$ & $\begin{array}{c}0.01 \\
{[0.39]}\end{array}$ & $\begin{array}{l}0.003 \\
{[0.06]}\end{array}$ \\
\hline Insider Ratio & $\begin{array}{l}-0.21 \\
{[-0.98]}\end{array}$ & $\begin{array}{l}-0.25 \\
{[-1.17]}\end{array}$ & $\begin{array}{l}-0.18 \\
{[-0.88]}\end{array}$ & $\begin{array}{l}-0.16 \\
{[-0.34]}\end{array}$ & $\begin{array}{c}0.63 \\
{[1.06]}\end{array}$ \\
\hline Leverage & $\begin{array}{c}-0.08^{* * *} \\
{[-7.72]}\end{array}$ & $\begin{array}{c}-0.07^{* * *} \\
{[-4.02]}\end{array}$ & $\begin{array}{c}-0.07^{* * *} \\
{[-3.63]}\end{array}$ & $\begin{array}{c}-0.08^{* *} \\
{[-2.13]}\end{array}$ & $\begin{array}{l}-0.07^{*} \\
{[-1.77]}\end{array}$ \\
\hline M/B Ratio & $\begin{array}{l}0.002 \\
{[0.43]}\end{array}$ & $\begin{array}{c}-0.01 \\
{[-0.96]}\end{array}$ & $\begin{array}{l}0.003 \\
{[0.50]}\end{array}$ & $\begin{array}{l}-0.01 \\
{[-0.85]}\end{array}$ & $\begin{array}{c}0.04^{* *} \\
{[2.06]}\end{array}$ \\
\hline Std dev (ROA) & $\begin{array}{c}0.15^{* *} \\
{[2.39]}\end{array}$ & $\begin{array}{c}0.18^{* * *} \\
{[4.09]}\end{array}$ & $\begin{array}{c}0.23^{* * *} \\
{[3.75]}\end{array}$ & $\begin{array}{c}0.27 * * * \\
{[2.77]}\end{array}$ & $\begin{array}{c}0.56^{* * *} \\
{[3.48]}\end{array}$ \\
\hline Std dev (Sales/TA) & $\begin{array}{c}-0.17 \\
{[-1.62]}\end{array}$ & $\begin{array}{c}-0.13 \\
{[-1.27]}\end{array}$ & $\begin{array}{l}-0.24^{*} \\
{[-1.84]}\end{array}$ & $\begin{array}{l}0.32 \\
{[1.41]}\end{array}$ & $\begin{array}{c}-0.75^{* *} \\
{[-2.31]}\end{array}$ \\
\hline $\begin{array}{c}\text { Include fixed effects? } \\
\text { (Industry \& Year) }\end{array}$ & Yes & Yes & Yes & Yes & Yes \\
\hline Adjusted $R^{2}$ & $70.85 \%$ & $74.72 \%$ & $73.25 \%$ & $64.14 \%$ & $48.17 \%$ \\
\hline No. of firm-year observations & 479 & 479 & 479 & 371 & 381 \\
\hline No. of unique firms & 243 & 243 & 243 & 187 & 193 \\
\hline
\end{tabular}

This table presents the regression results on CFO compensation which is expressed in natural logarithm, separately for Bonus, Salary, Total cash compensation, Total non-cash compensation and Total compensation. The sample is for the years 2006 to 2010. Firm Size is book value of total assets in the prior year, expressed in natural logarithm. Bus. Segments is the number of firm's business segments, expressed in logarithmic scale. Leverage is firm financial leverage, calculated as total debt divided by market value of equity. $M / B$ Ratio is market value of equity divided by the book value of equity. $R O A$ is return on assets, calculated as earnings before tax divided by total assets. Stock Returns is raw return on company's shares during the year, calculated as the current year share price divided by the previous year share price, expressed in natural logarithm. Discret. Accruals is the absolute value of forward-looking discretionary accruals from the modified Jones (1991) model, developed by Dechow et al. (2003). Std dev (ROA) is standard deviation of ROA over the last 5 years. Std dev (Sales/TA) is standard deviation of the ratio of sales divided by total assets. CFO Board is a binary variable coded as one if the CFO is on the company board of directors, zero otherwise. CFO Ownership is the percentage of company shares owned by the CFO, expressed in natural logarithm. CFO Tenure is the number of years since the CFO was appointed, expressed in natural logarithm. Board Size is the number of directors on the board of directors. Insider Ratio is the percentage of executive directors on the board. Each regression uses White (1980) heteroskedasticity consistent covariance estimates. It also includes industry-specific and year-specific fixed effects to control for systematic differences in compensation across industries and over time. Figures in square brackets are $t$-statistics. Emboldened figures indicate statistical significance at $10 \%$ level or better with *, **, *** indicating statistically significant at the $10 \%, 5 \%$ or $1 \%$ level. 